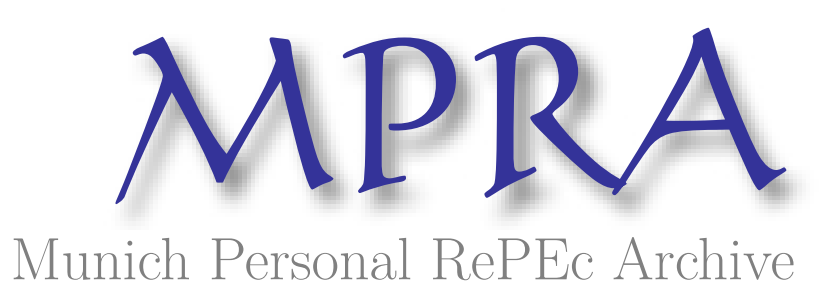

\title{
Why Companies Fail? The Boiling Frog Syndrome
}

Ozcan, Rasim

IsDB

2018

Online at https://mpra.ub.uni-muenchen.de/85413/

MPRA Paper No. 85413, posted 25 Mar 2018 07:10 UTC 


\title{
WHY COMPANIES FAIL? THE BOILING FROG SYNDROME
}

\author{
by
}

\section{Rasim Ozcan}

\begin{abstract}
Why nations fail? An answer is given by Acemoglu and Robinson (2012) by pointing out the importance of institutions for an economy that leads to innovations for economic growth. Christensen (2012) asks a similar question for a firm and diagnoses why companies fail. In this study, I relate Acemoglu and Robinson (2012) with Christensen (2012) in order to better understand how to make companies more prosperous, more powerful, healthier, and live longer via innovations.

Keywords: Why Nations Fail, Why Companies Fail, Capitalist's Dilemma, Innovations, Boiling Frog Syndrome

JEL Classification: D02, D20, 010
\end{abstract}

\section{Why Nations and Companies Fail?}

Even the once considered great companies fall and disappear after a while. An immediate question follows: what makes a company more healthy, more prosperous, and powerful? Is it the resources they have or is it the way the resources are used? An analogous question -why nations fail- is 
answered by Daron Acemoglu and James Robinson in their book "Why Nations Fail: The Origins of Power, Prosperity and Poverty." ${ }^{1}$

According to Acemoglu and Robinson, institutions is the key to explaining economic development differences between nations rather than geographic reasons, i.e. resources. One nation might have abundant resources but this doesn't necessarily mean that the nation would be prosperous and away from poverty. Whether the nation has a good set of institutions decides the prosperity level. They give anecdotal evidences from old times to the modern world. (Of course one may claim that without abundant resources, a nation cannot achieve full economic development; the role of geography is much more important. Please note that the controversy over the roles of geography and institutions in economic development is a long debated topic that is beyond the scope of this article.)

The striking example they give is the city of Nogales right at the border between Mexico and the US that is divided by fences into two parts, the US part -the north Nogales, and the Mexican part -the south Nogales. There are big differences between the north and the south Nogales not only in income levels but also in schooling, infant mortality, life expectancy and so on. However, there is not much difference between the people in terms of their culture, origin or so, if there is any at all. In addition, one side of the fences does not get more rain or natural resources than the other side. Hence, these cannot be the source of differences between the north and the south of Nogales. Rather it is the institutions they have at each side that create the differences. This is the explanation given by Acemoglu and Robinson (2012).

Why are institutions so important and make incredible difference at the end of the day? It allows a running government, just judicial system, well operating markets under the protection and regulations of the government and its laws, protection of intellectual products, and most of all, for the purposes of this article, creating a much friendlier environment for innovation in all areas including production of goods, services and processes.

Innovation is the key. It greases the wheels of the economy so that they run smoothly and faster without groaning and wearing out much. If innovations are not there, the wheels will lose their grease, hence speed and pace. At some point, the system will fall apart.

\section{Asking the Right Question}

We can think of companies as the wheels of an economy. If anyone wants to have a well running economy, greasing it is the solution. But that means greasing companies in that economy. In a more formal language, leading companies to innovate is the key in running an economy well.

\footnotetext{
${ }^{1}$ Acemoglu and Robinson (2012).
} 
At this point the question turns into what kind of grease should be used? i.e. innovations are of the essence, but are all innovations the same; if not, then what kind of innovations are beneficial? What kinds of innovations make companies more prosperous, powerful, healthier, and live longer?

These questions are rephrased in a condensed way and are answered by Clayton Christensen in his 2012 New York Times article - A Capitalist's Dilemma, Whoever Wins on Tuesday."2 He names the problem as "a capitalist's dilemma." Together with Derek van Bever, Christensen revisits the problem in an article - The Capitalist's Dilemma, at June 2014 issue of the Harvard Business Review (HBR) in detail. $^{3}$

Recall that in modern teachings of an economics course, the basic problem is the maximization of profit with respect to scarce resources: land, labor and capital. If a resource is abundant, it does not pose any restriction the problem of a firm, hence can be dis-regarded or that source can be wasted should there be need for. Some of you may raise your eyebrow as if "so? Where do you want to go from this?" Before taking you to the answers, let's refresh our memories about the quantitative easing one (QE1) that the FED carried out, and then QE2 and then QE3 and then searching of exit strategies by the FED in recent years together with European Central Bank's (ECB) actions making capital almost free drawing down the interest rates close to zero. Under such abundant capital, the assumption of -capital is scarce- is not valid anymore. Rather than being scarce, capital is abundant. So, does it make any difference? If so, how? What would be the effect on the maximization problem results?

Christensen (2012) draws peoples' attention to the abundant capital, hence, is changing conditions at the basic maximization problem of a modern firm. In other words, maximizing profit with respect to the scarce resources -land and capital- is not the correct problem to solve anymore since capital is not scarce presently.

\section{Abundant Capital, Types of Innovations and Right Metrics}

Indeed, capital is at everywhere but nobody wants to invest in innovations that grease the wheels of the economy that will lead growth. Before going forward, Christensen defines types of innovations as if answering the question posed above. There are three types of innovations: empowering, sustaining, and efficiency innovations in Christensen (2012).

Empowering innovations "transform complicated and costly products available to a few into simpler, cheaper products available to the many... Empowering innovations create jobs, because they require

${ }^{2}$ Christensen (2012).

${ }^{3}$ Christensen and Bever (2014). 
more and more people who can build, distribute, sell and service these products. Empowering investments also use capital - to expand capacity and to finance receivables and inventory." ${ }^{4}$ One may think of development of computers from big and heavy devices to today's tablet computers and smart phones as empowering innovations.

Sustaining innovations "replace old products with new models... They replace yesterday's products with today's products and create few jobs. They keep our economy vibrant - and, in dollars, they account for the most innovation. But they have a neutral effect on economic activity and on capital." 5 Automatic cars provide more convenience but every time a person buys a car he/she has to make a choice between an automatic car and a stick shift.

Efficiency innovations "reduce the cost of making and distributing existing products and services." Innovations on existing products and services that reduce the cost of making and distributing them are called efficiency innovations. These have two crucial functions: the first is raising up productivity, and the second is freeing up capital for more productive uses. Although the first is essential to be successful in competition, it may cause an undesired byproduct, eliminating jobs due to automation. ${ }^{6}$ Walmart's business model is an example of efficiency innovation.

Empowering innovations create jobs and increase consumption by its very definition. Efficiency innovations destruct jobs but free up capital. If the freed up capital is invested in empowering innovations and its job creation is higher than efficiency innovations' destruction, then such an economy grows.

Christensen and Bever (2012) rename sustaining and empowering innovations in more market friendly names as performance-improving and market-creating innovations respectively.

Thanks to Christensen (2012) and Christensen and Bever (2012), there is a prescription for companies to grow and hence for economies. However, if it is so easy, why do we see failures then?

The answer is the incentive set used -for the economics crowd and metrics, key performance indicators used -for the business crowd. If they are not aligned right with the goal, and calibrated well, the results will divert from growth to either slowed growth, or even worse no growth at all. In this discussion one needs to keep the basic problem of the modern firm in mind: maximization of profit subject to the scarce resources like capital.

\footnotetext{
${ }^{4}$ Christensen (2012).

${ }^{5}$ Christensen (2012).

${ }^{6}$ For more on this topic, see, Ozcan (2017a) and Ozcan (2017b).
} 
However, that produces metrics like return on net assets (RONA), return on capital employed (ROCE), or internal rate of return (I.R.R.). These are ratios. Innovations can be done to get better ratios, and those would not be empowering innovations, rather, they are sustaining and efficiency innovations that do not create growth. "Continuing to measure the efficiency of capital prevents investment in empowering innovations that would create the new growth we need because it would drive down their RONA, ROCE and I.R.R." ${ }^{\prime 7}$

\section{Conclusion: Boiling Frog Syndrome}

Given an incentive scheme, decision makers make their decisions accordingly. That is to say an executive does what is right from his/her perspective under the assumption that the capital is scarce. However, as pointed out earlier capital is no longer scarce, which changes the whole question, and the solution. Hence, there is the dilemma, as named by Christensen (2012) as the capitalist's dilemma; doing right things in the wrong scenarios. According to Christensen and Bever (2012) "[d]oing the right thing for long-term prosperity is the wrong thing for most investors, according to the tools used to guide investments. In our attempts to maximize returns to capital, we reduce returns to capital." 8

The choice is in between investing in empowering innovations that would take some years on the current measures, hence worse ratios now; and doing just sustaining and efficiency innovations to free up capital in order to have better ratios in order to be considered successful today but suffer in the long run due to lack of empowered innovations, what I call the boiling frog syndrome.

Hence, understanding the types of innovations, application of the boiling frog syndrome to the subject and existence and meaning of the capitalist's dilemma are the initial crucial steps in preventing companies from failure.

\section{References:}

Acemoglu, D. and J. Robinson (2012) Why Nations Fail: The Origins of Power, Prosperity and Poverty, London, New York, Crown Publishers.

Christensen, C. (2012) “A Capitalist's Dilemma, Whoever Wins on Tuesday," New York Times.

Christensen, C and D. Bever, (2014) "The Capitalist's Dilemma," Harvard Business Review.

\footnotetext{
${ }^{7}$ The Innovator's Dilemma: When New Technologies Cause Great Firms to Fail

${ }^{8}$ Christensen and Bever (2014).
} 
Christensen, C (2013) The Innovator's Dilemma: When New Technologies Cause Great Firms to Fail, Harvard Business Review Press, Boston, MA.

Ozcan, R. (2017a), "Robots Replacing Humans Creative Destruction or Total Annihilation?," IDB Chief Economist Complex Policy Brief No.10. Available at SSRN: https://ssrn.com/abstract=3144331

Ozcan, R. (2017b), "Robots, Skills and Income," IDB Chief Economist Complex Policy Brief No.13. Available at SSRN: https://ssrn.com/abstract $=3144362$ 